\title{
Does St. Paul Believe in Original Sin? Yeah, but so What?
}

\author{
Daniel Spencer \\ University of St Andrews
}

\begin{abstract}
In this article, I discuss the extent to which St. Paul's view of the doctrine of Original Sin ought to be taken as authoritative for confessing Christians today. I begin with the observation that there are, in the main, two camps represented in the contemporary literature. On the one hand, there are those who affirm the presence of Original Sin in Rom. 5, and consequently embrace the doctrine; on the other hand, there are those who deny Original Sin any substantive anchor in the text, and as a result conclude it is not necessary to believe today. I argue that things are not so straightforward, and present what I take to be a legitimate via media between these two positions. In the first main section of the article, I argue on exegetical grounds that Rom. 5:12-21 can be rendered adequately intelligible only when we admit that something like the Augustinian view of Original Sin is present at least in nuce. This I attempt to demonstrate in conversation with Douglas Moo and C. E. B. Cranfield (plus a bonus thought from Luther). While not, of course, the full-blown Augustinian doctrine, St. Paul's mind is, I contend, much nearer to the former's view of Original Sin than is commonly supposed. However, in the second main section I turn my attention to the question, So what? I discuss a number of theological and exegetical considerations which make it clear, I think, that St. Paul is not urging belief in Original Sin so much as he is utilizing an "intertestamental expansion" of an OT text to paint a picture about Christ and what we ought to believe about him. As such, I encourage and defend the application of a relatively mild hermeneutical principle which will allow the theologian a clear and biblically faithful way around the doctrine of Original Sin, if this is what is desired.
\end{abstract}

\section{Introduction}

Did St. Paul believe in Original Sin? And, if so, must Christians today? If by Original Sin we mean, roughly, that family of views which aims to account for the ubiquity of sin, suffering, and death through an appeal to a Fall from a primordial state of innocence, then the answer to the first question must surely be an affirmative. If,

Journal of Analytic Theology, Vol. 9, Summer 2021

10.12978/jat.2021-9.030011181517

(C) 2021 Daniel Spencer • (C) 2021 Journal of Analytic Theology 
however, we narrow the scope to refer to the broadly Augustinian ${ }^{1}$ sense whereby Adam's sin and guilt are, in some manner, imputed to all his descendants, then the more popular answer today, it seems to me, is "No, Paul did not believe in Original Sin." ${ }^{2}$ Now, in the recent literature this first question has been frequently posed with an eye to proffering a judgment on the second of these questions, thus reinforcing one of two divergent theological systems. On the one hand, an affirmative evaluation is taken to yield a more traditional theological vision in which strong accounts of the Fall and Original Sin feature as essential conceptual components of the Christian faith. On the other hand, a negative answer is said to (help) sanction a theology which maintains that an abandonment of these doctrines does precious little to compromise orthodoxy-I shall call this the "nonlapsarian" view. ${ }^{3}$ In this paper, however, I want to propose something of a via media between these two approaches which will, I hope, shed new light on some of the central issues at play. I do not think things are so simple as saying "St. Paul said it, therefore I believe it," or, alternatively, "St. Paul did not say it, therefore I do not need to believe it." My own assessment of the debate has already been given away in the title. To the above questions my answer-and this paper's thesis-is this: Yes, St. Paul believed in Original Sin, but so what? By itself, this does not suffice to compel Christian assent today.

This essay shall proceed in two stages. First, I want to discuss in some depth the all-important Rom. 5:12-21 text where I shall argue that something like an Augustinian view of Original Sin is present at least in nuce, and, if seriously reflected upon, in all likelihood rather more pronounced than many contemporary commentators are willing to entertain. Indeed, the reticence of many to admit a bona fide doctrine of Original Sin in Rom. 5 revolves around the concern that to do so would be to wind up in precisely these Augustinian waters. As we shall see, this worry has led to a few shady exegetical moves. But it need not be so. For, in the second part of this paper, I shall enlist a relatively modest hermeneutical principle which will make it possible to sidestep Paul's view of Original Sin all the same. ${ }^{4}$ Central to the elaboration of this principle is recognition of the fact that Paul is not interpreting the Genesis story so much as he is employing one particular interpretation of it in order to make a point about Christ. From this initial observation I shall attempt to derive the aforementioned hermeneutical principle

\footnotetext{
1 Though it is incorrect to understand "Augustinian" to mean Augustine is uniquely responsible for this doctrine. No doubt its historical popularity is due chiefly to the influence of the African bishop, but similar themes-including Seminal Identity and Original Guilt-may be found, to varying degrees, in the writings of many other Church Fathers, both East and West (contra the widely held view that, in the words of Toews [2013], "without exception among the Greek theologians, the inheritance from Adam's sin was mortality and corruption only" (p. 60). Cf. Weaver [1983], 188). See, for instance, Kelly (1955), 350; Reeves and Madueme (2014), 209 n1. 2 Though, I would hasten to add, Romans commentators seem to be almost 50/50 on the issue. ${ }^{3}$ Several examples of the former camp may be found in the edited volume Adam, The Fall, and Original Sin, eds. Madueme and Reeves (2014); a more recent example of this latter approach would be Hays (2018). Though seldom explicitly stated, it seems to be widely assumed that if Adam's sin was his alone, there is little need to consider it particularly relevant to the task of Christian theology (much less afford it central dogmatic status, as has been done traditionally). Certainly, we can agree, the problem of a historical Adam thereby becomes appreciably less pressing.

${ }^{4}$ As we shall see, this principle will allow one to reject any doctrine of Original Sin, if that is what is desired.
} 
and offer a brief defense. If successful, the upshot will be that Paul's classic statement of Original Sin need not be taken as theologically authoritative-the starting point, it seems to me, of much prior work in analytic theology on Original Sin. ${ }^{5}$ Thus, the fundamental question I seek to address has not so much to do with the degree to which our thought must cohere with that of the Apostle (or, metaphysically, how this might be so), ${ }^{6}$ but, rather, whether it must do so at all in this particular case. Is it really true, as McCall has recently said, that "the fact of original sin is beyond dispute for Christians" $(2019,203)$ ? In sum, this paper seeks to demonstrate how the following claims can be compatible:

1) St. Paul held to a fairly robust doctrine of Original Sin.

2) Scripture is a unique and authoritative source for theological reflection.

3) It is possible that the doctrine of Original Sin is false.

I should also emphasize that I am not arguing Original Sin should not be believed; only that it may faithfully be disbelieved. With this proviso in mind, we shall waste no further time and proceed straightway to St. Paul's putative notion of Original Sin. ${ }^{7}$

\section{Original Sin in Rom. 5:12-21}

\subsection{Preliminary Considerations}

12 Therefore, just as sin came into the world through one man, and death through sin, and so death spread to all men because all sinned ${ }^{\mathbf{1 3}}$-for sin indeed was in the world before the law was given, but sin is not counted where there is no law. ${ }^{\mathbf{1 4}}$ Yet death reigned from Adam to Moses, even over those whose sinning was not like the transgression of Adam, who was a type of the one who was to come.

15 But the free gift is not like the trespass. For if many died through one man's trespass, much more have the grace of God and the free gift by the grace of that one man Jesus Christ abounded for many. ${ }^{16}$ And the free gift is not like the result of that one man's sin. For the judgment following one trespass brought condemnation, but the free gift following many trespasses brought justification. ${ }^{\mathbf{1 7}}$ For if, because of one man's trespass, death reigned through that one man, much more will those who receive the

\footnotetext{
${ }^{5}$ See, for instance, Rea (2007); Hudson (2009) and (2014); Crisp (2015); McCall (2019), ch. 4. For a recent study that is unique in allowing for elaboration in both traditional and nonlapsarian directions, see Houck (2020).

${ }^{6}$ I have in mind here especially Rea (2007) and Hudson (2009) and (2014).

${ }^{7}$ My own view is that Original Sin does in fact refer to a genus rather than a single species (e.g., the Augustinian view). This genus includes the Eastern Orthodox idea of ancestral sin. When I refer specifically to the Augustinian view in the following pages, it should be understood to involve both Adam's Fall (peccatum originale originans) and the consequent condemnation of humanity in Adam (Original Guilt as a component of peccatum originale originatum).
} 
abundance of grace and the free gift of righteousness reign in life through the one man Jesus Christ.

18 Therefore, as one trespass led to condemnation for all men, so one act of righteousness leads to justification and life for all men. ${ }^{19}$ For as by the one man's disobedience the many were made sinners, so by the one man's obedience the many will be made righteous. ${ }^{20}$ Now the law came in to increase the trespass, but where sin increased, grace abounded all the more, ${ }^{21}$ so that, as sin reigned in death, grace also might reign through righteousness leading to eternal life through Jesus Christ our Lord. (ESV)

We have before us, then, St. Paul's famous argument in Romans 5 which, alongside Genesis 2-3, is the locus classicus for the doctrine of Original Sin (Blocher 1997, 63). At risk of oversimplifying things slightly, we may say that there are among commentators two general tendencies exhibited when approaching the question of Original Sin in this passage. There are on the one hand those who affirm the doctrine's presence ${ }^{8}$ - at times this is done rather hastily ${ }^{9}$ or without expressly mentioning the words "Original Sin," 10 and on other occasions great pains are taken explicitly to defend this reading. ${ }^{11}$ On the other hand, of course, there are those who categorically deny that Original Sin is to be found here, ${ }^{12}$ preferring at most to speak of "Original Death" (e.g., Dunn 1988, 273). Among this latter category of writers, however, it is not always plain Original Sin per se really is being rejected; sometimes an explicit statement on the matter is followed by comments which, to all appearances, imply some form of Original Sin, thus rendering the writer's final position somewhat opaque. ${ }^{13}$ We are not surprised, then, to find that exponents of both approaches often fail to provide anything like a clear definition of Original Sin. ${ }^{14}$ Indeed, on both sides it is very commonly assumed without argument that this doctrine connotes basically the Augustinian ideas of Seminal Identity and Original Guilt alone, ${ }^{15}$ a datum which, I would reemphasize, is almost certainly the raison d'être of our second group.

Before formally entering this debate, a few preliminary observations are in order. Each of these will be quite straightforward and relatively uncontroversial, and so the citations will for this portion flow rather liberally from both camps. We can begin by noting that, whether the initial "therefore" (dia touto) is taken to

\footnotetext{
${ }^{8}$ Even if sometimes rather different things are meant by Original Sin.

${ }^{9}$ See, for instance, Bruce (1974), 125-133.

10 Nygren (1952), 206-229; Barth (1956); de Boer (1988), 141-180. See also, perhaps, Dodd

(1932), 78-83, though it is difficult to say with confidence where exactly he stands.

${ }^{11}$ For example, Moo (1996), 314-350; Morris (1988); Blocher (1997), 63-81; Williams (1929), 124-134, though with some tight qualifications (see 156-57); Luther (1960), 77-82; Caballero (2014); McCall (2019), 177-184.

12 See Dunn (1988), 270-300; Cranfield (1980), 269-295; Barrett (1971),109-119; Käsemann (1980), 139-158; Scroggs (1966), 76-82; Ziesler (1989),143-153; Harrisville (1980), 82-87; Smith (1953), 171-74.

13 This is true of Käsemann (1980) and, to a lesser extent, Barrett, Cranfield, and Dunn. Käsemann appears to refuse Original Sin "an anchor in the text," but goes on to posit a "burdening curse" to which each individual is inescapably subject (147-49). I suspect a clearer definition of Original Sin would have helped to tidy up this ambiguity.

14 This is, of course, true specifically of commentaries and not works on Original Sin.

15 See Moo (1996), 326-27, Bruce (1974), 129-130; Scroggs (1966), 78; Käsemann (1980), 14748; Harrisville (1980), 84.
} 
signal a summing up of 5:1-11 only ${ }^{16}$ or the entire argument of Romans thus far, ${ }^{17}$ this subsection is without a doubt a central component of Romans as a whole. ${ }^{18}$ Indeed, as Moo points out, in light of 5:1-11 especially, it may be more apt to see in this passage the basis for the preceding argument rather than its conclusion: we are enabled to hope and rejoice in God precisely because "whatever we have lost in Adam we have gained in Christ" $(1996,317)$. Put simply, this is not a text to be dealt with flippantly: tampering heedlessly with the foundations will always threaten to flatten the edifice as a whole. We shall keep this especially in mind when, presently, we begin to do a bit of tampering ourselves.

There is also what Käsemann calls the "giant anacoluthon" beginning in v. 12 (1980, 146). Paul here begins a comparison ("just as"-hosper) which he fails to carry through to its completion: "just as sin came into the world through one man ..." We should expect soon enough the linking phrase houtos kai (so also), but it never comes in this verse. Though there is still perhaps some uncertainty here, it appears safe to say with the majority of commentators that, after the break, ${ }^{19}$ the comparison resumes in full force in vv. 18 and $19 .{ }^{20}$ It is thus not altogether unwise to follow Karl Barth's suggestion of reading vv. 18 and 19 immediately following v. 12 best to grasp Paul's point $(1956,7)$. But the break is important in its own right. As Dunn envisions it, while dictating v. 12 Paul "felt the need to pause and provide some clarification . . . even at the cost of leaving in suspense the first half of a balanced sentence" $(1988,290)$. As the argument wears on, Paul is forced to hold off even further on completing the comparison begun in v. 12. Dunn continues,

Like someone about to offer a clear-cut definition, who at the last moment realizes the definition is not quite so clear-cut after all, and who before the definition is complete begins to insert qualifying clauses which complicate the simplicity of the definition as originally conceived. So [sic] here Paul, initially struck by the parallel between Adam and Christ as epochal figures, catches himself and before completing the comparison hastens to emphasize the contrast between the two actions and their results (1988, 293).

Likewise, Cranfield speaks of the "vast dissimilarity between Adam and Christ," save only "in respect of the actual point of comparison" $(1985,112) .21$ For Paul, Christ and his salvific effects are in every way superior to Adam and the consequences he wrought; the two figures are comparable only insofar as both are "progenitors" of the human race (Barrett 1971, 114), one bringing death and condemnation, the other justification and eternal life.

\footnotetext{
16 As in C.E.B. Cranfield (1985), 110.

${ }_{17}$ As in Dunn (1988), 271-72. For a fuller range of options, see Moo (1996), 316-17; Morris (1988), 228, Cranfield (1980), 271.

${ }^{18}$ Cf. Dunn (1988), 271; Nygren, quoted in Morris (1988), 228: this is "the point where all the lines of (Paul's) thinking converge, both those of the preceding chapters and those of the chapter that follow."

19 There is no consensus where exactly the break occurs in verse 12. See Moo (1996), 319.

${ }^{20}$ Cranfield (1980), 272-73, Moo (1996), 318-19, Morris (1988), 229, Dunn (1988), 290.

21 This, it appears, is Paul's point in vv. 15-17.
} 


\subsection{The Presence of Original Sin}

We may now tentatively join the ranks of those who do in fact see a true doctrine of Original Sin in this great passage. It will conduce to clarity to consider the arguments of two commentators in particular: I take Cranfield as my delegate for the dissenting opinion, and I follow the argument of Moo for our positive judgement. Additional support will of course be sought where required, but the arguments of Cranfield and Moo are both robust enough to stand on their own and sufficiently representative of the arguments generally given in each camp that we can, for the most part, simply fix our attention here. We shall begin with Cranfield and then, with Moo, offer what I take to be a powerful refutation of the dissenting view.

\section{2a. C. E. B. Cranfield}

The natural starting point for any discussion of our present theme is of course the final clause of v. 12: eph ho pantes hemarton. In line with the preponderance of contemporary New Testament scholars, Cranfield translates eph ho as "because," yielding "because all (have) sinned" (1980, 269, 274-79; 1985, 113-14). He is quick to point out that this does not immediately imply the Augustinian theory has no basis in the text: "the question has still to be asked," he says, "whether 'sinned' refers to men's participation in Adam's sin ... or to men's own personal sinning" (1985, 113-14). Though he opts for the latter reading, Cranfield reminds us that the former position is "strongly supported by a good many interpreters" (1985, $114),{ }^{22}$ giving the lie to the popular claim that the idea behind Augustine's in quo omnes peccaverunt mistranslation is utterly unsupportable by the Romans text. ${ }^{23}$ Still, Cranfield rejects this reading on two grounds: first, no indication is given of hemarton being used in anything but the ordinary sense of personal sinning; second, the former reading falsely presupposes that Adam and Christ are in this comparison to be taken as equivalent in every respect. He says, "there is no reason to assume that, because he believed Christ to be the sole source of men's righteousness, Paul must have regarded Adam equally as being alone responsible for men's ruin" $(1985,114 ; 1980,278-79)$. Therefore, with regard to the question of Original Sin, the thrust of v. 12 is merely this: "human death is the consequence of human sin" $(1980,281)$. Death initially enters the world through Adam's transgression and remains a permanent fixture in the human experience only through the continued sinning of each individual $(1980,281 ; 1985,115)$. In other words, it is only because Adam's descendants themselves sin that they, too, ultimately succumb to death (cf. Ziesler 1989, 147).

Thus far, I see no reason to contest Cranfield's claims; as we will see, Moo's rebuttal succeeds even if all this is correct. ${ }^{24}$ But what does Cranfield make of vv.

\footnotetext{
22 Two such interpreters are Bruce (1974), 129-130 and Morris (1988), 230-32.

${ }^{23}$ As in Harrisville (1980), 84. Cf. Bruce (1974), 130: "Although the Vulgate rendering of [eph ho] by 'in whom' may be a mistranslation, it is a true interpretation."

${ }^{24}$ Cf. Blocher (1997), 71: "The case [for Original Sin] does not (contrary to a superficial understanding of the issues) rest on the rendering of the connecting words at the end of verse 12 for which Augustine finally settled.... Whatever the choice, it does not preclude an Augustinian interpretation of the whole passage."
} 
18-19? Surely, we think, there is more potential for a doctrine of Original Sin here. ${ }^{25}$ Cranfield thinks not, however. After skimming over v. 18a as a simple repetition of the protasis in $\mathrm{v} .12 \mathrm{a}(1980,289)$, he follows in v. 19 what appears to be a standard move among the dissenters, maintaining that v. 12 is, in effect, the standard by which Paul's words in vv. 18-19 are to be judged. ${ }^{26}$ In light of the interpretation given of eph ho in v. 12, it is to be assumed that by "the many were made sinners" (v. 19) Paul means "all other men (Jesus alone excepted) were constituted sinners through Adam's misdeed in the sense that, sin having once obtained entry into human life through it, they all in their turns lived sinful lives" (1980, 290-91; cf. 1985, 121). In short, vv. 18a and 19a are to be understood primarily as restatements of the idea first conveyed and inelegantly elaborated in v. 12 (cf. Dunn 1988, 283). Accordingly, the doctrines of Seminal Identity and Original Guilt are wholly absent from the text, and so it can be concluded that Original Sin-narrowly understood-finds no place in the thought of St. Paul. Of course, we must be strongly inclined to think only that Cranfield supposes he has disposed of the doctrine; given a broader, less tendentious definition of Original Sin, it is certain he does ascribe to Paul at least a weak version of the doctrine. ${ }^{27}$

\section{2b. Douglas Moo}

Turning now to Moo's counterargument, we first note that his thought is entirely consonant with that of Cranfield up to a point. Moo, too, takes eph ho pantes hemarton to mean "because all sinned," and in the very same sense Cranfield defends. Hence Moo, "Paul's concern in this verse, and throughout the passage, is not with 'original sin', but with 'original death'." (1996, 323). In v. 12, then, Paul merely claims that "the causal nexus between sin and death ... has repeated itself in the case of every human being," and goes no further $(1996,323)$. While this is precisely the point at which our dissenters customarily drop any discussion of Original Sin, ${ }^{28}$ Moo goes on. For at the end of v. 12, Paul leaves us with a question that demands an answer: what relation, if any, is there between Adam's sin and ours-and why do all sin? This problem, Moo writes, is only aggravated by vv. 1819 where we are informed that Adam's sin led to condemnation for all-more, that

\footnotetext{
${ }^{25}$ Consider the judgement of Nygren (1952), 222: "It is good here to look back to verse 12 . If we be likely to interpret its statement 'because all men sinned' to mean that, according to Paul, death has its dominion over all men because they all have sinned, then we meet the direct refutation of any such interpretation in verse $17 . "$

${ }^{26}$ Herein we find a key interpretive difference between our two groups. For other examples of "dissenters" who see v. 12 dictating and conditioning vv.18-19, see Ziesler (1989), 151; Scroggs (1966), 82 where these verses are "essentially summaries of what has already been said"; Dunn (1988), 283 where v. 18 is only a "masterly compression" of the preceding verses and v. 19 is a mere "summary" of 12-18. Harrisville (1980) doesn't so much as raise the question (85-86), and Hays (2018) has altogether too little to say (196-98). The same may be said for Käsemann (1980), who says virtually nothing about these verses and their potential connection with Original Sin (156-58). Barrett (1971), it seems, recognizes there is more fodder for the doctrine in v. 19 than in v. 12, but casually dismisses the idea that Original Sin (by which he means Seminal Identity) might be present (111). Even McCall (2019), an interpreter highly sympathetic to Original Sin, does not make much of these verses (178-182). It is as if the protases in vv. 18 and 19 say nothing new and are, as it were, contained analytically within v. 12.

${ }^{27}$ And this even in the absence of what he will go on to say (see immediately below, in I.2b).

28 See fn. 26 above.
} 
by it "the many were made sinners." Thus, Moo argues, we are confronted with a difficulty $(1996,323)$ : "how can we logically relate the assertions 'each person dies because each person sins [in the course of history]' and 'one man's trespass led to condemnation for all people'?"

Moo then presents four options one might endorse in order to solve this problem. First is the Pelagian view, which denies any relationship between Adam's sin and ours: we sin "in imitation of Adam, but there is nothing in Adam's sin that makes it necessary that we $\sin ^{\prime \prime}(1996,323$ n51). According to Moo, however, this view is "not very widely held in our day" for the simple reason that "the text so clearly makes the sin of Adam to be, in some sense, the cause of universal condemnation" (324 n51). Another tack one might take is simply to leave the tension unresolved; this is in large measure the approach adopted by Dunn: "Paul refuses to be drawn into a more rigorously defined and consistent systematization of his theology, thus leaving space both for the diversity of opinion and the silence of agnosticism," Dunn avers $(1988,298,290)$. This line is not so much rejected by Moo as it is cautiously set to one side: while it is true that one should be careful not to impose an alien theology on the thought of a biblical writer, still it behooves the exegete to "pursue reasonable harmonizations that the author may assume or intend" (Moo 1996, 325).

The third possibility Moo cites is especially interesting insofar as it is the one explicitly endorsed by Cranfield, and this despite the latter's apparent desire to distance St. Paul from the doctrine of Original Sin. ${ }^{29}$ How does the trespass of one result in condemnation for the many? For Cranfield, the answer is that Adam's descendants inherited from him "a nature weakened and corrupted" $(1980,279)$. Human nature itself was vitiated by the first sin in such a way that, thenceforth, human sinning and therefore death became an inevitability (Moo 1996, 325). This surely resolves the logical difficulty, but only at considerable interpretive cost. For, as Moo indicates, the plain truth is that it is only via the most egregious of exegetical contrivances that it becomes possible to find something like this present in the Romans text. ${ }^{30}$ Indeed, Cranfield advances this thesis entirely uncritically, providing us with no textual justification for the introduction of a corrupted nature. It is, rather, a purely philosophical move, suggested for the sake of resolving a logical worry which issues from the ambiguous language of the Apostle himself. ${ }^{31}$ In passing, it would be well to recall that the corruption of human nature which resulted from the Fall is a deeply Augustinian conviction; consequently we see that Cranfield has, at the end of the day, failed to purge St. Paul entirely of his tacit Augustinianism anyway.

Finally, we come to the solution espoused by Moo himself. If we read v. 12 in light of vv. 18-19-and not exclusively the other way around ${ }^{32}$-we discover that, short of adopting one of the three aforementioned approaches, we are all but forced to admit a "corporate" element to Adam's sin: we have all, in some sense, sinned "in and with" Adam (Moo 1996, 326). Moo explains,

\footnotetext{
${ }^{29}$ See Cranfield (1980), 279; Cranfield (1985), 114. I deliberately passed over this in the preceding discussion in order to introduce it more appropriately here.

30 See Moo (1996), 326. Cf. Morris (1988), 231.

${ }^{31}$ Cf. Tennant (1903), 261: "it is quite plain that a mental interpolation of some kind is necessary, if we are to extract any definite meaning at all from S. Paul's language”; cf. also Dunn (1988), 290. 32 Again, see fn. 26.
} 
This is not to adopt the translation 'in Adam' rejected above. The point is rather that the sin [in v. 12d] attributed to the 'all' is to be understood, in the light of vv. $12 \mathrm{a}-\mathrm{c}$ and $15-19$, as a sin that in some manner is identical to the sin committed by Adam. Paul can therefore say both 'all die because all sin' and 'all die because Adam sinned' with no hint of conflict because the sin of Adam is the sin of all $(1996,326)$.

To the objection that neither is this idea of "corporate personality" 33 obviously at work in the text it may be replied that it is, in fact, both a natural and necessary postulate if we are to make sense of v. 19 at all. ${ }^{34}$ It is natural because it would require the addition of no middle term (such as a corrupted nature): the many were made sinners directly because of the one's disobedience, and not because, à la Cranfield, the one's disobedience led to a second state of affairs which ultimately culminated in the many becoming sinners. 35 Thus the notion of corporate personality would enable the most straightforward reading of v. 19: "Adam is conceived as standing in a causal relation to the subsequent death, sin, and condemnation of his descendants-nothing less than this can be meant" (Williams 1929, 131). ${ }^{36}$ Moreover, this idea was, in any case, rather popular among many Jews in Paul's day, and so it is not unlikely we should find it at play here (Moo 1996, 327; cf., e.g., 4 Ezra 7:118). And finally, our participation in Adam's sin is also a necessary postulate inasmuch as it is the only remaining plausible option, that is, if our desire is to render the passage reasonably intelligible. Moo's argument thus appears to be altogether strong; certainly it outshines the argument deployed by Cranfield in defense of the dissenting opinion. ${ }^{37}$

\section{2c. Further Considerations}

There is, perhaps, one further item to mention before wrapping up the present section, by all appearances a theme only seldom discussed. ${ }^{38}$ In his famous Commentary on Romans, Martin Luther spearheads his attack on the Pelagian interpretation of Rom. 5:12 with a characteristically Augustinian consideration:

\footnotetext{
${ }^{33}$ For this idea see, for instance, Bruce (1974), 126; Dodd (1932), 80; de Boer (1988), 160-61. Moo (1996), 327. Dunn (1988) argues negatively that it is "more of a hindrance than a help here" (272).

${ }^{34}$ As Moo (1996) notes, this idea was quite popular in Paul's day, and so there is every reason to suppose it may have been utilized by the Apostle to paint a Christological picture (327-28).

35 Cf. Morris (1988), 240: "It does not mean that sinless people were compelled to become sinners, but rather that Adam's sin constituted them as sinners" (emphasis mine); Moo (1996), 326.

${ }^{36}$ Contra Dunn (1998), 95: "the causal connection implied here by 'made' (katestathèsan) may be nonspecific and very loose, 'made' functioning simply as equivalent to 'became' (egenonto)." If Dunn is right, one is left wondering why Paul decided to use katestathēsan to begin with. Once more, it would seem that the interpretation of v. 19 is being controlled unilaterally by eph ho in v. $12 \mathrm{~d}$.

37 As McCall (2019) helpfully points out, Moo does not think we can choose between "federalist" and "realist" theories (p. 182). The crucial commonality, however, is a commitment to Original Guilt (see pp.161-170).

${ }^{38}$ Among my dissenting sources, I find only Cranfield (1980) touches on it-and only very briefly (279).
} 
"clearly," he says, "[Paul] is speaking of original sin; for if death comes by sin, then also the little children have sinned who die. So this must not be understood in the sense of actual (personal) sin" $(1960,77)$. The thought is transparent enough: if St. Paul here only means to say that the individual dies on account of his own sin, that "all men die because they have personally sinned" (Leenhardt 1961, 144), then we are once again faced with a glaring predicament. The infant, for instance, obviously does not sin-why then does he die? It will scarcely suffice to respond, as Cranfield does, that "those who die in infancy are a special and exceptional case" and so we must assume Paul to be speaking of adults $(1980,279)$. Of course he is speaking primarily of adults. But the point is that, conceptually, we stand in need of an explanation of this grim reality-a reality of which Paul is assuredly well aware but fails explicitly to mention. Unless, then, we are to count the Apostle a singularly shallow thinker, we must suppose that he considered death to be a consequence of rather more than merely individual sin. Were Paul truly of the mind that death would not befall those without personal sin, ample witness to the falsity of his claim would have bombarded him from all flanks. Hence, either Paul is not thinking enormously clearly, or else he has in mind something that points in the general direction of Seminal Identity or even Original Guilt. Thus, it is possible Luther has given us an additional reason to imagine that St. Paul does in fact subscribe to some fairly robust-if underdeveloped and ill-defined-doctrine of the Fall and Original Sin.

Having said all this, however, surely there is still room to sympathize with Dunn's judgement that Paul is, intentionally or otherwise, declining to elaborate a fully consistent and orderly account of Adam's sin (1988, 290, 298). As Robert Mackintosh puts it, one senses that "St. Paul, instead of stating his views in full, [has] thrown at us shorthand notes in a foreign language which we know very imperfectly" $(1913,84)$. To anticipate the conclusion of our next section, Paul's relative nonchalance vis-à-vis the nature of the first sin does appear to indicate his main concern ultimately lies elsewhere. ${ }^{39}$ Nevertheless, if the foregoing argument is sound, we can see that Paul's incomplete theory would still rationally necessitate further amplification in the direction of a more rigorous-dare I say Augustinian-account of Original Sin. Perhaps Paul's own mind never progressed substantially beyond an inchoate notion of the adverse effects produced by Adam's sin; if so, he would upon further reflection be compelled either to drop the notion altogether, or else proceed to develop the doctrine more systematically along the lines indicated above. But granted that his general socio-religious milieu would have all but forced his hand in interpreting the Adam tale along largely historical and realistic lines, ${ }^{40}$ we can confidently conclude that further reflection would have resulted in the latter possibility. Thus is St. Paul seen in Rom. 5:12-21 to be committed at least implicitly to a more familiar form of Original Sin. If, then, the theological imperative is to achieve doxastic conformity with the biblical writers on every subject (so far as this is possible), it appears likely that a broadly Augustinian approach to Original Sin is inescapable.

\footnotetext{
${ }^{39} \mathrm{Cf}$. Tennant (1903), 253: "the indefinite language of the apostle necessarily appears ambiguous to generations which have attempted to advance to [sic] precise and definitely formulated views on the subject upon which he touches but incidentally."

40 See Dunn (1998), 84-90 and the rather lengthy discussion of this in chapter 2 of LegarretaCastillo (2014), 33-117, esp. 96ff.
} 


\section{So What?}

We have now come to the second stage of our discussion on St. Paul and Original Sin. The argument of this section should be straightforward enough, and we have already laid out much of the necessary groundwork required for its elucidation above. Supplied with the conclusion that there is, after all, a reasonably strong doctrine of Original Sin to be found in the writings of St. Paul, how can one then deny it is a necessary part of Christian confession? The problem seems to strike two separate chords. First and most obviously is the issue of authority: Original Sin is, we are compelled to admit, in some sense "scriptural." Thus it would appear that to reject the doctrine outright would be to snub the biblical witness as well. Secondly, we face the issue of doctrinal removal-in other words, heresy, defined by Belloc as "the dislocation of some complete and self-supporting scheme by the introduction of a novel denial of some essential part therein" $(2015,8) .{ }^{41}$ Granted that the doctrine of Original Sin conforms to the requirements of the Vincentian Canon, ${ }^{42}$ it would seem just obvious that to remove it from one's systematic theology would necessarily be to court heresy. As a response to the latter charge, it might be suggested that Original Sin, however understood, is not obviously an essential component of the Christian religion. ${ }^{43}$ That it can be discarded with no serious harm done to other central Christian convictions is a wider project that falls decidedly outside the scope of this paper; ${ }^{44}$ for now, we will concentrate on the first of these problems and attempt to determine what sort of hermeneutical move is required to ensure that disbelieving Original Sin does not fairly fly in the face of scriptural teaching. In order to arrive at an explicit statement and defense of this move in §III.2-3, however, I think it necessary first of all to pinpoint St. Paul's central focus in Rom. 5. For if it can be demonstrated that Adam is at best peripheral to Paul's primary concerns, surely the objection under consideration will lose some of its initial bite.

\footnotetext{
41 The word "heresy," Belloc explains, comes from the Greek haireo: I grasp, seize, or take away (2015, $8 \mathrm{n} 1)$.

42 N.P. Williams (1929) has established this point beyond any reasonable doubt.

${ }^{43}$ So long, that is, as we are taking care not to conflate the doctrine of Original Sin with other related doctrines. It is all too easy to forget the technicalities involved in the formal doctrine and thus, with Chesterton, decry "certain new theologians" for questioning "the only part of Christian theology which can really be proved." This is, of course, a misunderstanding of 'Original Sin': Chesterton means only to denounce those who "deny human sin" and reject the existence of "positive evil," neither of which I do here. See Chesterton (1909), 22-23. See also F.R. Tennant's (1902) magnificent discussion of this erroneous "identity of observed fact with theoretical explanation" (p. $10 \mathrm{n} 1$ ), 5-10. He says, "It is most important to distinguish these two ideas which so many writers on human sinfulness have confused... That man ... is at perpetual strife with himself, is a fact of universal experience which has found expression in all literatures, heathen and Christian. But it is quite another question whether this state is to be regarded as a disease, a confusion, or even in any strict sense a 'discord,' produced once and for all in human nature" (p. 9 n1). We must by all means keep these two very separate ideas straight.

${ }^{44}$ For my response to the common objection that eliminating Original Sin would prove disastrous for theodicy, see Spencer (2020).
} 


\subsection{The Centrality of Christ}

To help frame this discussion, it is well worth stating explicitly that the account of Adam's sin given by Paul in Rom. 5 stems from but one of many interpretations of the Genesis 2-3 narrative on offer within second temple Judaism. ${ }^{45}$ There is, for instance, the "scholastic, orthodox, official" view of the Rabbis which saw in Adam's fall merely the forfeiture of certain (increasingly fanciful) supernatural enhancements and the introduction of death (Tennant 1903, 145, 176; cf. Williams $1929,71-72$ ). Then there is the view taken by the writer of the Book of Jubilees in which Adam is, through copious revisions of the original plot, "portrayed in a positive fashion as the first patriarch and priest who kept the Law, and as an example to follow for the author's generation" (Legarreta-Castillo 2014, 70). And, of course, there is also the approach found briefly in 4 Ezra, a tradition ostensibly embodied in part 46 by St. Paul himself: "For what good is it to all that they live in sorrow now and expect punishment after death? O Adam, what have you done? For though it was you who sinned, the fall was not yours alone, but ours also who are your descendants" (7:118). ${ }^{47}$ The variety of interpretations on offer does not, of course, entail that Paul was mistaken; rather, it serves mainly to highlight the contingency involved in Paul holding to his particular interpretation, as well as to unmask the popular notion that there is only one way to understand the figure of Adam. ${ }^{48}$ There is thus every reason to suppose one could take a divergent approach to the first sinner and yet concur on the general nature and framework of redemption.

More to the point, however, it does seem that in Romans 5 itself Paul's understanding of Adam is largely immaterial. All through, the spotlight is fixed firmly on Christ and the redemptive effects he brings: "its focus," says Moo, "is not on sin, original or otherwise. Rather, it focuses on righteousness and life" (2001, 103). As we have said, Paul takes great pains to emphasize as strongly as possible the utter incommensurability between Christ and Adam, excepting only the present point of comparison. ${ }^{49}$ Both are, in Dunn's language, "epochal figures" in the sense that Adam and Christ both represent in themselves the two sole and mutually exclusive existential realities to which any given human being may be said to belong (1988, 289; cf. Käsemann 1980, 158). We are, by default, born united to the Adamic humanity which remains captive to the reign of sin and death-but thanks be to God through Jesus Christ our Lord, in and through whom we triumph over both and "reign in life." 50 This is "the idea which has stood at the

\footnotetext{
45 See Tennant (1903), chs. 5-10; Legarreta-Castillo (2014), ch. 2; Williams (1929), lecture 2, esp. 53-60, 70-84. For a much shorter summary of such interpretations, see Enns (2012), 99-103.

${ }^{46}$ But, as Bruce (1974) reminds us, "none of these writers (i.e., Ben Sira and the authors of Wisdom and 4 Ezra) sees anything of the deeper significance in the fall of man which is now unfolded by Paul" (129). Cf. Nygren (1952), 208.

${ }^{47}$ Add to this the fact that the 'Watcher-legend' of Gen. 6 evidently predated the traditional Fall story as an explanation for death and universal wickedness, and we see further that the elimination of one particular interpretation of Gen. 2-3 by no means places an entire religious system in jeopardy (see Williams [1929], 20ff.).

48 More recent investigation of Gen. 2-3 has often yielded interpretations of Adam which, despite certain merits, would very likely have been unknown to Paul. See, for example, Barr (1992); Smith (2019).

${ }^{49}$ See Cranfield (1980), 269-270.

50 Cf. Rom. 7:21-25; 1 Cor. 15:56-57; 2 Cor. 2:14.
} 
center of the whole discussion about Adam and Christ" (Nygren 1952, 229), and it is the conclusion Paul repeats time and again throughout the letter and elsewhere. ${ }^{51}$ It is en Christo that we are set free from the "law of sin and death" (Rom. 8:2), able to "do all things" (Phil. 4:13), and "transformed into the same image from one degree of glory to another" (2 Cor. 3:18). Indeed, the great thrust of all Pauline theology can equitably be said to consist precisely in this. For Paul, "Christ is the thread which runs through all, the lens through which all comes into focus, the glue which bonds the parts into a coherent whole" (Dunn 1998, 726). It is not Adam with whom Paul is finally concerned-on the contrary, it is Christ.

Viewed in this light, it becomes less plausible to maintain that Paul is here promoting or even expounding a doctrine of Original Sin. True enough, he believes in it-at least this is the conclusion to which we have been driven by a close look at Rom. 5:12-21. But belief in Original Sin hardly entails it is actively being promoted; on the contrary, in the present case it would be far more accurate to say that Paul is merely employing the doctrine in order to advance a more central and fundamental claim about Christ. ${ }^{52}$ On this all commentators are agreed. 53 Now, based on what the Apostle tells us about Christ's saving effects throughout both this passage and 5:1-11, it would appear that the lone prerequisite for redemption is an antecedent enslavement of human beings to three things in particular: (a) weakness and ungodliness, (b) sin, and (c) death (vv. 6, 8, 12, 17, $19,21) .54$ These "prerequisites" can, I think, almost certainly be obtained in the absence of a doctrine of Original Sin; consequently, the latter need not be posited for the Apostle's main point to remain intact. For, to my mind no less than to Paul's, "Christianity is Christ" and not Adam (Dunn 1998, 729). Twenty centuries hence, then, we may perhaps say this: it is not quite true that Christ removes Adam's effects-rather, Christ removes a reality the existence of which may be (and has been) explained with recourse to Adam's primal sin. But since Christ and the salvation found in him can be fully had apart from such a sin, this negative judgement with regard to the necessity of Original Sin in no way compromises the essence of the Christian faith. ${ }^{55}$

\footnotetext{
${ }^{51}$ For instance, Rom. 6:5ff., 7:21-25, 8:9ff., 8:37-39; 1 Cor. 15:12ff.; 2 Cor. 5:16-21; Phil. 3:8-11; Col. 2:13-15.

52 To be more precise, we might stress that he is utilizing one vision of Adam in particular by which his theological point about Christ may best be made. We may here cite James Barr's judgement: "Paul was not interpreting the story in and for itself; he was really interpreting Christ through the use of images from this story." See Barr (1992), 89.

53 See, for example, Scroggs (1966), 81-82, Moo (1996), 315 and Moo (2002), 103-104; Nygren (1952), 228-29; Morris (1988), 240-42; Dunn (1988), 290; Seifrid (2007), 627-28.

${ }^{54}$ Cf. Enns (2012), 123: the "three core elements" of Paul's thought here are death, sin, and the death and resurrection of Christ.

55 Cf. Brunner (1942), 142: "In the doctrine of the New Testament all that matters is this: the unity of the human race in sin as the counterpart of the unity of redeemed humanity in Christtype and anti-type" (emphasis mine). While Brunner interprets Genesis 3 along very traditional lines, he nevertheless appears to recognize its second-class status in Paul's thought. He goes on to argue that the ecclesiastical doctrine of Original Sin is correct insofar as it attests to "the union of all in creation and sin," but ultimately misfires inasmuch as it dogmatizes a particular, "incomprehensible" origin story (p. 143).
} 


\subsection{A Hermeneutical Presupposition}

The current essay is not, of course, the place to develop and defend in full a particular doctrine of the inspiration of scripture. Nevertheless, a word or two must be said in this connection, for it is clear that the legitimacy of the above analysis as a faithful reading of scripture depends vitally on a certain hermeneutical maneuver. In this section, we will turn our attention to a more explicit consideration of what precisely that maneuver is, after which we will consider some further applications in its defense.

The three most important findings of the preceding section, it seems to me, may be summarized as follows:

(1) St. Paul's view of Adam is (and was) but one plausible interpretation of Gen. 2-3.

(2) In the context of Rom. 5, Adam and his sin are used to paint a larger picture; they are not being elaborated for their own sake.

(3) There is no essential connection between Paul's view of Original Sin and his soteriological vision-the latter can plausibly be secured without reference to the former.

Now, a brief comment on each for clarification:

(1) Again, nothing of substance follows from this necessarily. It may be the case that faithful biblical interpretation demands that we strive for "doxastic conformity with the biblical writers on every subject" (with precedence given, perhaps, to the New Testament where relevant-as it is here). On this view, the abundance of competing interpretations would be completely beside the point: St. Paul is the privileged interpreter who accurately conveys the sense and abiding relevance of Gen. 2-3. This, however, seems problematic for a reason to be explored below, viz., that consistent application of this (or a similar) principle would lead, if not to absurdities, then to some conclusions which must strike us as prima facie bizarre. 56

(2) This, we may say, is fairly typical of Paul. As Richard Hays has pointed out, "for Paul, original intention is not a primary hermeneutical concern." Rather, "eschatological meaning subsumes original sense" $(1989,156)$. The interest of Adam for Paul in this passage is, we may plausibly surmise, basically utilitarian: "Struck by the parallel between Adam and Christ as epochal figures," we have heard Dunn say $(1988,293)$, Paul "sees in it a glowing opportunity to coin a metaphor" by utilizing a text that is, for him, simply given (Hays 1989, 140; cf. 24). ${ }^{57}$ Once more, it may be emphasized that this does not in principle rule out a tighter hermeneutic such as the one suggested immediately above. But it does indicate, I think, a clear path towards a more flexible one which might consist preeminently in an amplified sensitivity to the rhetorical function and intention of various types of intertextual citation. Which direction, in other words, is the author pointing?

\footnotetext{
${ }^{56}$ See $§ I I I .3$ below, as well as fn. 59, 60 .

57 This quote is taken, in fact, from Hays's discussion of Paul's use of Ex. 34 in 2 Cor. 3. In addition to its felicitous transposition into our Rom. 5 context, it serves also as an example of this strategy being "fairly typical of Paul."
} 
(3) If Paul's understanding of Adam were plausibly the conditio sine qua non of salvation in Christ, a much stronger burden would have to be borne by the nonlapsarian theorist. And perhaps for Paul it was such a condition. But, it seems to me, if it is possible to secure the enemies to be overcome without reference to Paul's mode of explaining them, then this burden need not be satisfied-that they are in fact overcome is what is important. As William James once said, "here is the real core of the religious problem: Help! help!" $(1985,162)$ In Christ we have our help indeed; it would be strange (to say the least) to insist that Christ is impotent to vanquish sin and death but for the primal sin of the first man.

Let us suppose that these three considerations suffice to ground the legitimacy of a move away from belief in Original Sin. What, then, is the implicit hermeneutical principle at play which enables this move? It is, I think, straightforward enough:

(H) When, in a given scriptural passage $\mathrm{P}$, a source external to $\mathrm{P}$ is employed in the service of a more fundamental theological point (i.e., used as an illustration), the propositional content of this illustration need not be believed if both of the following conditions are met:

$\left(\mathrm{H}^{1}\right)$ Where another passage from scripture serves as the illustration's source, other reasonable 58 understandings of the source text are available;

$\left(\mathrm{H}^{2}\right)$ The theological point can be true (and have the same meaning) in the absence of the illustration.

It will be seen that $(\mathrm{H})$ pertains to $(2)$ above, $\left(\mathrm{H}^{1}\right)$ to $(1)$, and $\left(\mathrm{H}^{2}\right)$ to (3). On the whole, this principle appears to be rather minimal, and does not seem to carry with it any glaring, untoward ramifications. ${ }^{59} \mathrm{~A}$ very similar principle is, in fact, implied in the distinction Nicholas Wolterstorff draws between the "noematic content" and "designative content" of a given passage, though it seems to me that $(\mathrm{H})$ goes a bit further in indicating precisely when the distinction may be deployed to advance additional theological claims. For Wolterstorff, the historical situatedness of the biblical writers may, in select cases, require that later interpreters set aside the time-bound language and concepts utilized by an author-the noematic content-whilst still affirming the driving theological picture these concepts help to paint-the designative content. ${ }^{60}$ It is the latter

\footnotetext{
58 Of course what might count as "reasonable" would be difficult precisely to demarcate (not to mention controversial), but I take it most would agree that there are some objective standards in the matter. For our purposes here, I would submit that a certain reading is known to be reasonable if it can readily be found endorsed in the relevant scholarly literature (e.g., in academic commentaries on Genesis, will we commonly find interpretations of Adam and the Fall other than Paul's own?). In the main, the primary question would be: are there other ways the original audience of the source text might have understood the author's intent?

${ }^{59} \mathrm{~A}$ further question would be the extent to which $(\mathrm{H})$ might be applied to certain sayings of Christ (e.g., Matt. 24:37-39: "For as were the days of Noah, so also ...") Unfortunately, the intricacies involved in this discussion would take us much too far afield; suffice it to say that, for many, considerably more is at stake in the case of Christ holding false (peripheral) exegetical or theological beliefs, and, more generally, Christ is to be taken as sui generis.

${ }^{60}$ As an example, Wolterstorff cites the geocentric cosmology operative in Ps. 93: "The world is established; it shall never be moved. Your throne is established from of old; you are from
} 
which, in cases covered by $(\mathrm{H})$, is uniquely authoritative and may be said to convey the abiding sense of the passage for later generations of readers. Once more, we see the importance of clearly sifting "the point, or the main point, that the author wishes to make" from "the author's particular way of making or developing that point" (Wolterstorff 1995, 209). Let us now turn to some potential parallels to Rom. 5 to ascertain how well $(\mathrm{H})$ might serve the theologian seeking to circumvent Original Sin.

\subsection{Further Reflection on (H)}

To help gauge the plausibility of $(\mathrm{H})$, it will be instructive to consider the principle in action elsewhere. I want, therefore, to look at three other applications of (H)one purely fictitious and two taken from other locations in the New Testament. ${ }^{61}$ I present them in order of increasing analogical commensurability with Rom. 5.

To begin, suppose St. Paul had substituted Prometheus for Adam: "For as by Prometheus's duplicity great pain befell humankind, so by Christ's integrity and faithfulness the many are made whole." In this instance, of course, no one would argue that we should feel compelled to accept the existence of the Titans, and I am not sure this would change even if Paul appeared to believe in them himself (though I may be wrong about that). This is, I freely concede, a rather crude illustration, but the role of $(\mathrm{H})$ should be evident: A source external to Rom. 5 (Hesiod) is being used to shed light on, or illustrate, a more fundamental point about Christ's saving faithfulness; $\left(\mathrm{H}^{1}\right)$ does not apply because the illustration does not involve a biblical text; since Christ's saving faithfulness, I suspect, is not logically wedded to the existence of Prometheus, $\left(\mathrm{H}^{2}\right)$ is satisfied. In this case, we may say it is by virtue of $(\mathrm{H})$ that the theologian would be entitled to reject the historicity of the proposition expressed in the dependent clause and simultaneously affirm the truth of the proposition in the independent clause.

Let us now proceed to the New Testament itself. One potential analogue to Adam in Rom. 5:12ff. can, I think, be found in the Epistle of Jude. We are informed in v. 9 that the archangel Michael, "contending with the devil, was disputing about the body of Moses." But here, as in our Romans passage, Jude's aim is not to articulate what ought to be believed about this unusual tale; rather, exactly like Paul in Rom. 5, he is utilizing an "intertestamental expansion" of an Old Testament narrative (Davids 2006, 59) to serve his true point (H) (Horrell 1998, 107). He is calling attention to certain "ungodly people" in the church (v. 4) who, under the

everlasting." The important thing, Wolterstorff thinks, is the affirmation that God is "from everlasting" - the erroneous cosmology is certainly utilized to predicate something true of God, but the falsity of the former in no way impugns the truth of the latter. Presumably, then, Wolterstorff is hinting at something very much like $\left(\mathrm{H}^{2}\right)$; this is confirmed in a further illustration of his I freely adapt here: If I point to an ailing sapling, exclaim, "that elm needs water right now!" and proceed to water it, it would be of little practical significance to tell me the tree was really a sycamore and not an elm. My misidentification is, in this case at least, irrelevant to my saving the tree. What is relevant is the correct identification of some sort of tree and the diagnosis of its need for water. And, I think, the same may plausibly be said mutatis mutandis of Original Sin in Rom. 5. See Wolterstorff (1995), 209-211.

61 This is, of course, in addition to the examples already cited in fn. 59 and 60. 
pretext of prophecy, presumptuously "blaspheme the glorious ones"62 (v. 8). But the true saint, following in the example of Michael, would not dare even to blaspheme the devil (v. 9) (Davids 2006, 62). But, of course, Jude's point remains intact even if we happen to disbelieve the propositional content of the illustration used $\left(\mathrm{H}^{2}\right) .\left(\mathrm{H}^{1}\right)$, too, is no less evidently satisfied: if the episode in question relies on a gloss on Zech. 3 (Stokes 2017, 200ff.), one may appeal to the existence of variant interpretations of the latter; if Jude utilizes the Assumption of Moses only, then $\left(\mathrm{H}^{1}\right)$ need not factor into our hermeneutical deliberations at all. In short, $(\mathrm{H})$ authorizes the Christian to doubt the historical accuracy of this legend found in Jude. But if this is right, then he may well be entitled to doubt St. Paul's ideas about the Fall and Original Sin as well.

Even this Jude analogue is imperfect, however. While it does, in all likelihood, involve a "devotional expansion" of a contentious Old Testament text (Hays 1989, 49), there is not much riding either theologically or philosophically on the historicity of the episode. Moreover, to return to a point raised nearer the opening of this paper, it is hardly as if Jude's illustration is wielded at a pivotal moment in a foundational text for Christian theology. This no doubt establishes a serious chasm between the illustrations found in Jude and Rom. 5; whether the chasm is unbridgeable, however, may be considered against the backdrop of another crucial Pauline text.

When we turn to the curious "allegory" in Gal. 4:21-31, we find a remarkable parallel to our Rom. 5 text. ${ }^{63}$ In a radical reworking of Gen. 21:1-10, Paul roundly-and audaciously-declares that Hagar and Sarah are to be understood as figures for the Sinaitic covenant and the older Abrahamic covenant now fulfilled in Christ, respectively. ${ }^{64}$ But the Apostle goes further in the unmistakable hope of claiming all the homiletical chips on the table: "Now you, brothers, like Isaac, are children of promise. But just as at that time he who was born according to the flesh persecuted him who was born according to the Spirit, so also it is now" (Gal. 4:28-29). I shall allow Hays to describe the situation for us in his own words:

If Ishmael is the persecutor of Isaac, then the very persecuting activity of the Torah advocates aligns them with the slave offspring rather than with the child of promise. ... The argument is clever, except for one problem: the text of Genesis does not say that Ishmael persecuted Isaac. Indeed, most modern readers of Genesis 21 would surely suppose that it was the freewoman Sarah who, on behalf of Isaac, instigated a persecution of the innocent and powerless Hagar and Ishmael. No doubt Paul's argument presupposes a longstanding Jewish tradition of exonerating Sarah's apparently vicious jealousy by supplying a provocation on the basis of Gen. 21:9: "Sarah saw the son of Hagar the Egyptian, whom she had borne to Abraham, playing" (mesaheq; LXX adds, "with her son Isaac"). Into the single word playing, later rabbinic commentators read all manner of

\footnotetext{
${ }^{62}$ Among other things. Note also that the "glorious ones" (doxas) are probably (good) angels (see Davids [2006], 56 and 62; cf. Horrell [1998], 121-122).

${ }^{63}$ I here follow Hays (1989), 84-121.

${ }^{64}$ Paul does not say, as the ESV misleadingly renders, "this may be interpreted allegorically"; rather, hatina estin allègorumena- "these things are allegorical" or "figurative."
} 
mischief, including mockery, idolatry, child molestation, and attacks with bow and arrow $(1989,117)$.

What have we here, then? Two observations are in order. First, if it is true that it behooves Christians to affirm whatever theological beliefs St. Paul set forth, we find ourselves presently in a somewhat awkward circumstance. We must apparently believe, for one, not merely that Hagar and Sarah may serve as a useful, if fanciful, theological illustration for Christians today, but that this reading is in some sense the correct one. On the other hand, this strict hermeneutical stance would further require Christians to accept the highly dubious gloss on Gen. 21:9 which at once sees Ishmael as the prototypical persecutor of the people of God, as well as the figurative embodiment of "Judaizers" ancient and modern. While to maintain this in earnest is certainly possible, such a position surely presses the interpreter to the precipice of exegetical integrity. Secondly, note that, in contrast to the Jude passage, Paul's "hermeneutical miracles" here play a crucial role both in the argument of Galatians as well as in articulating a Christian understanding of the relationship between Christ and Law, Church and Israel (Hays 1989, 112). In short, we are not here dealing with trivialities of the sort encountered in the examples of Jude and Prometheus.

Once more, our proposed hermeneutical principle will grant us the doxastic flexibility needed to evade some potentially disquieting conclusions. As in Rom. 5, we are not forced simply to decide between accepting or rejecting a straightforward Old Testament narrative; rather, we are confronted with an "intertestamental expansion" or "homiletical commentary" (Hays 1989, 49) on an Old Testament narrative which is being utilized to furnish a broader theological point $(\mathrm{H})$. Nor can we seriously doubt that Gen. 21:1-10 might admit of other reasonable interpretations $\left(\mathrm{H}^{1}\right)$. But could Paul arrive at his understanding of Israel and the Church without his whimsical reading of this passage $\left(\mathrm{H}^{2}\right)$ ? I for one don't see why not.

Now, I am not so naïve as to suppose that my defense of this hermeneutical principle will be convincing to everyone. ${ }^{65}$ For others, $(\mathrm{H})$ will be, I imagine, rather obvious and hardly in need of any defense at all. My own personal inclination to accept it stems not simply from skepticism about various peripheral ideas found in scripture but, more fundamentally, from the suspicion that too much contemporary biblical theology implicitly proceeds along scripturally Docetic hermeneutical lines. ${ }^{66}$ As Enns explains, "What some ancient Christians were saying about Christ, the Docetic heresy, is similar to the mistake that other

\footnotetext{
${ }^{65}$ Hans Madueme has objected to an earlier, more simplistic formulation of this principle on the grounds that it might prove positively acidic, burning through virtually every view expressed in scripture, and not just the ones I have proposed. Whatever the merit of this objection to my earlier formulation, it will not work here. Take the story of Ananias and Sapphira in Acts 5 (proposed by Madueme himself). Surely the fundamental theological point has more to do with not hoarding personal finances than the odd tale of divine retribution? An analysis of $(\mathrm{H})$ will show where this objection misfires: $(\mathrm{H})$ First, it is not at all clear that the authorial intent is to make a larger theological point-it reads very much like Luke intends to recount something that genuinely happened, in line with the rest of Acts. More to the point, however, there is no external scripture involved here: the purported 'illustration' is the story itself. Acts 5 thus falls decisively outside the methodological net of $(\mathrm{H})$. The cases where $(\mathrm{H})$ might legitimately apply are actually few and far between.

${ }^{66}$ For "scriptural docetism" see Enns (2005), 18ff.
} 
Christians have made (and continue to make) about Scripture: it comes from God, and the marks of its humanity are only apparent, to be explained away" $(2005,18)$. On this view, scripture only seems to be human in various regards. But to demand that the biblical text be inerrant in the sense that every one of its claims-including those that serve merely as illustrations for a broader theological purpose-are to be believed would be, arguably, to neglect the indisputably genuine "human marks" of the scriptural witness which are ubiquitous and "thoroughly integrated into the nature of Scripture itself" (Enns 2005, 18; cf. Wolterstorff 1995, 209-211). And, it hardly need be said, such scriptural Docetism would appear to lead inevitably to the simplistic, overly rigid, and thoroughly fundamentalist interpretive rule we have had occasion to discuss already, the sum of which is, "This is what the Bible says. This is what we must believe" (White 1993, 64). Once we take care to recognize these "human marks," however, the hermeneutical principle we have been defending in fact appears exceptionally modest, and thus the argument of this essay becomes, to my mind at any rate, quite difficult to resist. In Rom. 5, we might say, it is the "human mark" evinced in Paul's view of Adam which successfully and compellingly testifies to the divine splendor revealed in the God-man Jesus Christ. ${ }^{67}$

A final comment may be made, too, on the inclusivity of $(\mathrm{H})$. The principle is deliberately phrased to allow for a wide range of interpretive preferences: "the illustration need not be believed." In any instance where $(\mathrm{H})$ can be applied appropriately, there may be additional considerations which lead an interpreter to retain the illustration in question. If, to take but one example, an interpreter is swayed by ecumenical consensus-as in the case of Rom. 5 vis-à-vis some doctrine of Original Sin-acceptance of $(\mathrm{H})$ will do nothing to discourage him from continuing to endorse the doctrine. Again, $(\mathrm{H})$ will tell us, maximally, only when it is safe or reasonable to disbelieve, not when it is unsafe or unreasonable to continue believing. This is, perhaps, especially true in the case of the Fall and Original Sin.

\section{Conclusion}

Hitherto the objective among detractors from the doctrine of Original Sin has been to deny that St. Paul has any serious opinion on the matter. But we have seen that this approach is misguided. In the first place, such an argument presupposes an unacceptably narrow definition of Original Sin, a conception under which only broadly Augustinian theories could possibly fall. But even the weakest imaginable rendering of Rom. 5:12-21 would still undoubtedly fit a more ecumenical (and precise) definition, and so on these grounds alone we see that the claim is highly problematic. Secondly, the argument that Paul's ideas about Adam in no way correspond to those of the later Augustinian tradition is difficult to sustain. For even if Paul did not quite believe the doctrines of Seminal Identity or Original Guilt himself, a strong case can be made that these conclusions would have been reached eventually had Paul been forced into further reflection. But we need not

\footnotetext{
${ }^{67}$ For further reflection on hermeneutics from an analytic perspective, see Swinburne's (2010) insightful discussion on the import of the Bible's "literary, social, and cultural contexts" for faithful biblical interpretation today (p. 209).
} 
concern ourselves too much with these issues, or so I have argued. For the path away from Original Sin, if such a path there be, will commence not in an endeavor fully to ascertain the mind of Paul, but rather in the recognition that his doctrine of Original Sin is, in the end, but a trifling theme which emerges only as a minor aide and servant to the centerpiece of his theology as a whole-that is, Christ, and we in him. Yes, St. Paul believed in Original Sin. So what? ${ }^{68}$

\section{References}

Barr, James. 1992. The Garden of Eden and the Hope of Immortality: The ReadTuckwell Lectures for 1990. SCM Press.

Barrett, C. K. 1971. A Commentary on the Epistle to the Romans. Adam \& Charles Black.

Barth, Karl. 1956. "Christ and Adam: Man and Humanity in Romans 5." Translated by T.A. Smail. Scottish Journal of Theology Occasional Papers 5 .

Belloc, Hilaire. 2015. The Great Heresies. Cavalier Books.

Blocher, Henri. 1997. Original Sin: Illuminating the Riddle. InterVarsity Press.

Bruce, F. F. 1974. The Epistle of Paul to the Romans. InterVarsity Press.

Brunner, Emil. 1942. Man in Revolt: A Christian Anthropology. Translated by Olive Wyon. Lutterworth Press.

Caballero, Juan Luis. 2014. "Rm 5,12 y el Pecado Original en la Exégesis Católica Reciente." Scripta Theologica 46: 121-140.

Chesterton, G. K. 1909. Orthodoxy. John Lane.

Cranfield, C. E. B. 1985. Romans: A Shorter Commentary. T\&T Clark. 1980. A Critical and Exegetical Commentary on the Epistle to the Romans. Vol. 1. T\&T Clark.

Crisp, Oliver D. 2015. “On Original Sin.” International Journal of Systematic Theology 17(3): 252-266.

Davids, Peter H. 2006. The Letters of 2 Peter and Jude. Eerdmans.

\footnotetext{
${ }^{68}$ I am indebted to Joshua Cockayne and Alan Torrance for providing helpful comments on earlier drafts of this paper, as well as to an anonymous reviewer whose many comments, concerns, and criticisms resulted in a much better piece of analytic-exegetical theology. The title of this piece is inspired by a moniker for an essay written by Ryan Mullins.
} 
de Boer, Martinus C. 1988. The Defeat of Death: Apocalyptic Eschatology in 1 Corinthians 15 and Romans 5. Sheffield Academic Press.

Dodd, C. H. 1932. The Epistle of Paul to the Romans. Hodder and Stoughton.

Dunn, James D. G. 1998. The Theology of Paul the Apostle. T\&T Clark. . Romans 1-8. 1988. Word, Incorporated.

Enns, Peter. 2012. The Evolution of Adam: What the Bible Does and Doesn't Say about Human Origins. Brazos Press.

2005. Inspiration and Incarnation: Evangelicals and the Problem of the Old Testament. Baker Academic.

Harrisville, Roy A. 1980. Romans. Augsburg Publishing House.

Hays, Christopher M. 2018. “A Nonhistorical Approach: The Universality of Sin without the Originating Sin." In Finding Ourselves after Darwin: Conversations on the Image of God, Original Sin, and the Problem of Evil, edited by Stanley P. Rosenberg, 187-202. Baker Academic.

Hays, Richard B. 1989. Echoes of Scripture in the Letters of Paul. Yale University Press.

Horrell, David G. 1998. The Epistles of Peter and Jude. Epworth Press.

Houck, Daniel W. 2020. Aquinas, Original Sin, and the Challenge of Evolution. Cambridge University Press.

Hudson, Hud. 2014. The Fall and Hypertime. Oxford University Press. 2009. "Fission, Freedom, and the Fall." In Oxford Studies in Philosophy of Religion, vol., 2, edited by Jonathan L. Kvanvig, 58-79. Oxford University Press.

James, William. 1985. The Varieties of Religious Experience: A Study in Human Nature. Penguin Books.

Käsemann, Ernst. 1980. Commentary on Romans. Translated by Geoffrey W. Bromiley. SCM Press.

Kelly, J. N. D. 1965. Early Christian Doctrines. Adam \& Charles Black.

Leenhardt, Franz J. 1961. The Epistle to the Romans: A Commentary. Translated by Harold Knight. Lutterworth Press.

Legarreta-Castillo, Felipe de Jesús. 2014. The Figure of Adam in Romans 5: The New Creation and Its Ethical and Social Reconfiguration. Fortress Press.

Luther, Martin. 1960. Commentary on the Epistle to the Romans. Translated by J. Theodore Mueller. Zondervan. 
Mackintosh, Robert. 1913. Christianity and Sin. Duckworth \& Co.

Madueme, Hans, and Michael Reeves, eds. 2014. Adam, the Fall, and Original Sin: Theological, Biblical, and Scientific Perspectives. Baker Academic.

McCall, Thomas H. 2019. Against God and Nature: The Doctrine of Sin. Crossway.

Moo, Douglas J. 2002. Encountering the Book of Romans: A Theological Survey. Baker Academic. 1996. The Epistle to the Romans. Eerdmans.

Morris, Leon. 1988. The Epistle to the Romans. Eerdmans.

Nygren, Anders. 1952. Commentary on Romans. Translated by Carl C. Rasmussen. SCM Press.

Rea, Michael C. 2007. “The Metaphysics of Original Sin.” In Persons: Human and Divine, edited by Peter Van Inwagen and Dean Zimmerman, 319-356. Oxford University Press.

Reeves, Michael, and Hans Madueme. 2014. "Threads in a Seamless Garment: Original Sin in Systematic Theology." In Adam, the Fall, and Original Sin: Theological, Biblical, and Scientific Perspectives, edited by Hans Madueme and Michael Reeves, 209-224. Baker Academic.

Scroggs, Robin. 1966. The Last Adam: A Study in Pauline Anthropology. Fortress Press.

Seifrid, Mark A. 2007. "Romans." In Commentary on the New Testament Use of the Old Testament, edited by G. K. Beale and D. A. Carson, 607-694. Baker Academic.

Smith, C. Ryder. 1953. The Bible Doctrine of Sin and of the Ways of God with Sinners. Epworth Press.

Smith, Mark S. 2019. The Genesis of Good and Evil: The Fall(out) and Original Sin in the Bible. Westminster John Knox Press.

Spencer, Daniel H. 2020. "Evolution, Middle Knowledge, and Theodicy: A Philosophical Reflection." Forum Philosophicum 25(2): 215-233.

Stokes, Ryan E. 2017. “Not over Moses' Dead Body: Jude 9, 22-24 and the Assumption of Moses in their Early Jewish Context." Journal for the Study of the New Testament 40(2): 192-213.

Swinburne, Richard. 2010. "What Does the Old Testament Mean?" In Divine Evil?: The Moral Character of the God of Abraham, edited by Michael Bergmann, Michael J. Murray, and Michael C. Rea, 209-225. Oxford University Press. 
Tennant, F. R. 1903. The Sources of the Doctrines of the Fall and Original Sin. Cambridge University Press. .1902. The Origin and Propagation of Sin. Cambridge University Press, 1902.

Toews, John E. 2013. The Story of Original Sin. Wipf and Stock.

Weaver, David. 1983. "From Paul to Augustine: Romans 5:12 in Early Christian Exegesis." St Vladimir's Theological Quarterly 27(3): 187-206.

White, J. Benton. 1993. Taking the Bible Seriously: Honest Differences About Biblical Interpretation. Westminster John Knox Press.

Williams, N. P. 1929. The Ideas of the Fall and of Original Sin: A Historical and Critical Study. Longmans, Green and Co.

Wolterstorff, Nicholas. 1995. Divine Discourse : Philosophical Reflections on the Claim that God Speaks. Cambridge University Press.

Ziesler, John. 1989. Paul's Letter to the Romans. SCM Press. 